\title{
Lability and Basicity of Bipyridine-Carboxylate- Phosphonate Ligand Accelerate Single-Site Water Oxidation by Ruthenium-Based Molecular Catalysts
}

\author{
D. W. Shaffer
}

Submitted to JACS

October 2017

\section{Chemistry Department}

\section{Brookhaven National Laboratory}

\author{
U.S. Department of Energy \\ USDOE Office of Science (SC), \\ Basic Energy Sciences (BES) (SC-22)
}

Notice: This manuscript has been authored by employees of Brookhaven Science Associates, LLC under Contract No. DE- SC0012704 with the U.S. Department of Energy. The publisher by accepting the manuscript for publication acknowledges that the United States Government retains a non-exclusive, paidup, irrevocable, world-wide license to publish or reproduce the published form of this manuscript, or allow others to do so, for United States Government purposes. 


\section{DISCLAIMER}

This report was prepared as an account of work sponsored by an agency of the United States Government. Neither the United States Government nor any agency thereof, nor any of their employees, nor any of their contractors, subcontractors, or their employees, makes any warranty, express or implied, or assumes any legal liability or responsibility for the accuracy, completeness, or any third party's use or the results of such use of any information, apparatus, product, or process disclosed, or represents that its use would not infringe privately owned rights. Reference herein to any specific commercial product, process, or service by trade name, trademark, manufacturer, or otherwise, does not necessarily constitute or imply its endorsement, recommendation, or favoring by the United States Government or any agency thereof or its contractors or subcontractors. The views and opinions of authors expressed herein do not necessarily state or reflect those of the United States Government or any agency thereof. 


\title{
Lability and Basicity of Bipyridine-Carboxylate-
}

\section{Phosphonate Ligand Accelerate Single-Site Water}

\section{Oxidation by Ruthenium-Based Molecular Catalysts}

\author{
David W. Shaffer, ${ }^{\dagger}$ Yan Xie, ${ }^{\dagger}$ David J. Szalda, Javier J. Concepcion ${ }^{\dagger} *$ \\ ${ }^{\dagger}$ Chemistry Division, Brookhaven National Laboratory, Upton, NY 11973-5000, USA. \\ *Department of Natural Sciences, Baruch College, CUNY, New York, New York 10010, USA.
}

\begin{abstract}
A critical step in creating an artificial photosynthesis system for energy storage is designing catalysts that can thrive in an assembled device. Single-site catalysts have an advantage over bimolecular catalysts because they remain effective when immobilized. Hybrid water oxidation catalysts described here, combining the features of single-site bis-phosphonate catalysts and fast bimolecular bis-carboxylate catalysts, have reached turnover frequencies over $100 \mathrm{~s}^{-1}$, faster than both related catalysts under identical conditions. The new $\left[(\mathrm{bpHc}) \mathrm{Ru}(\mathrm{L})_{2}\right]\left(\mathrm{bpH}_{2} \mathrm{cH}=2,2^{\prime}-\right.$ bipyridine-6-phosphonic acid-6'-carboxylic acid, L = 4-picoline or isoquinoline) catalysts proceed through a single-site water nucleophilic attack pathway. The pendant phosphonate base mediates $\mathrm{O}-\mathrm{O}$ bond formation via intramolecular atom-proton transfer with a calculated barrier of only $9.1 \mathrm{kcal} / \mathrm{mol}$. Additionally, the labile carboxylate group allows water to bind early in the
\end{abstract}


catalytic cycle, allowing intramolecular proton-coupled electron transfer to lower the potentials for oxidation steps and catalysis. That a single-site catalyst can be this fast lends credence to the possibility that the oxygen evolving complex adopts a similar mechanism. 


\section{Introduction}

As humanity continues to improve in renewable technologies for harvesting energy, so too must we improve in methods to store that energy for later use. A promising yet largely unrealized strategy for effective energy storage is through its conversion to chemical potential energy. ${ }^{1}$ The conversion of water to hydrogen or carbon dioxide to reduced carbon products such as methanol or ethanol can form the basis for a carbon-neutral fuel-energy cycle. The development of catalysts for these fuel-forming reactions is an active area of research. ${ }^{2}$ In addition, an effective water- or $\mathrm{CO}_{2}$-reducing system also requires an excellent oxidant-forming catalyst. The natural choice of oxidant is $\mathrm{O}_{2}$, produced by the oxidation of water. Water oxidation is a 4-electron, 4-proton process that requires the formation of an $\mathrm{O}-\mathrm{O}$ bond between two water molecules, and the efficiency of catalysts that promote this process lags behind other complementary processes such as hydrogen or carbon monoxide production. ${ }^{3}$ In particular, catalysts that function at low $\mathrm{pH}$ require further development. ${ }^{2,4,5}$ This is an area where molecular catalysts with organic ligands have the potential to outperform metal-oxide based catalysts.

Natural water oxidation is catalyzed by the oxygen-evolving complex (OEC) in photosystem II (PSII). Two general mechanisms have been proposed for the key O-O bond formation step in the OEC: (1) water nucleophilic attack (WNA) of a free ${ }^{6}$ or Ca-bound ${ }^{7-10}$ water molecule on a $\mathrm{Mn}^{\mathrm{V}}$ oxo or $\mathrm{Mn}^{\mathrm{IV}}$ oxyl and (2) $\mathrm{O}-\mathrm{O}$ radical coupling between either $\mathrm{Ca}$ and $\mathrm{Mn}$ oxyl radicals, ${ }^{11}$ or between a Mn-oxyl radical and a bridging Mn-oxo (I2M). ${ }^{12-15}$ Artificial molecular catalysts form O-O bonds through analogous mechanisms. ${ }^{16,17}$ Llobet and coworkers reported a dinuclear $\mathrm{Ru}$ catalyst for which $\mathrm{O}-\mathrm{O}$ bond formation takes place via intramolecular interaction of two $\mathrm{Ru}^{\mathrm{V}}$ oxo moieties with significant $\mathrm{Ru}^{\mathrm{IV}}$ oxyl character (intramolecular $\left.\mathrm{I} 2 \mathrm{M}\right)^{18,19}$. Sun and coworkers 
reported a family of mononuclear catalysts $\left(\left[(\mathrm{bda}) \mathrm{Ru}(\mathrm{L})_{2}\right]\right.$; bda ${ }^{2-}$ is $2,2^{\prime}$-bipyridine- $6,6^{\prime}-$ dicarboxylate, $\mathrm{L}$ is a monodentate ligand) with water oxidation rates comparable to that of the OEC using high concentrations of $\mathrm{Ce}^{\mathrm{IV}}$ as the sacrificial oxidant. ${ }^{20-22} \mathrm{O}-\mathrm{O}$ bond formation for these catalysts also takes place via radical coupling of two $\mathrm{Ru}^{\mathrm{V}}$ oxo moieties with significant $\mathrm{Ru}^{\mathrm{IV}}$ oxyl character, but in this case this key step is bimolecular (intermolecular I2M). ${ }^{21}$ While in solution these catalysts exhibit high turnover frequencies (TOF) and turnover numbers (TON), when tethered to a surface their bimolecular mechanism is severely inhibited and TOF decrease by more than three orders of magnitude. ${ }^{23}$

It was demonstrated relatively recently that only a single metal active site is needed to catalyze water oxidation. ${ }^{24-32}$ This revelation opened the door for the development of a large number of mononuclear single-site catalysts. ${ }^{33-35}$ Reported by Meyer and coworkers, the accepted mechanism for these single-site catalysts involves the generation of an electrophilic $\mathrm{Ru}^{\mathrm{V}}$ oxo, which then undergoes nucleophilic attack by a water molecule (WNA). ${ }^{24-28}$ The key aspect of the WNA mechanism is a concerted oxygen-atom proton transfer (APT) step in which the $\mathrm{Ru}^{\mathrm{V}}=\mathrm{O}$ transfers an oxygen atom to the incoming water molecule while an external base accepts a proton from the water molecule in a concerted fashion. This nomenclature originates from the analogy of this reaction to previously studied oxygen-atom transfer reactions from $\mathrm{Ru}^{\mathrm{IV}}$ oxos to phosphines, ${ }^{36-39}$ dimethylsulfide, and dimethylsulfoxide, ${ }^{40}$ in which the nucleophilic substrate attacks the electrophilic oxo. The highly organized nature of the APT step requires a significant entropic barrier, consistent with the fact that single-site catalysts are typically quite slow, especially at low $\mathrm{pH}^{28,33,41}$ Rates greater than $1 \mathrm{~s}^{-1}$ have only been measured electrochemically and at high $\mathrm{pH}$, where proton transfer is facile due to better proton-accepting buffers, or completely avoided due to significant concentrations of hydroxide. ${ }^{42,43}$ Several important 
questions arise: First, considering that the OEC oxidizes water on the millisecond timescale, is it reasonable to consider WNA as a potential mechanism for the OEC? Second, is it reasonable to pursue single-site catalysts that might never reach the required TOFs for potential applications in artificial photosynthesis? Batista and coworkers showed that some single-site catalysts are slowly but irreversibly converted to more robust oxo-bridged dinuclear catalysts and posed the question: is one site really enough? $?^{44}$

Local proton management is of key importance in the APT step for single-site catalysts. Recognizing this led to enhancements of up to $\sim 10^{4}$ in the rate constant for base-mediated APT by changing the $\mathrm{p} K_{\mathrm{b}}$ of the base of the buffer acting as the proton acceptor in this step (with catalytic rates increasing from $3.5 \times 10^{-3} \mathrm{~s}^{-1}$ to $4.8 \mathrm{~s}^{-1}$ with $\mathrm{H}_{2} \mathrm{O}$ and $\mathrm{HPO}_{3}{ }^{2-}$, respectively). ${ }^{33,35}$ Nevertheless, a significant entropic penalty is paid due to a highly organized transition state (TS) where the $\mathrm{Ru}^{\mathrm{V}}=\mathrm{O}$, the incoming water molecule, and the base are required to arrange in a specific orientation. ${ }^{33,41,45}$ We were able to circumvent this problem by strategically positioning the base as part of the ligand in catalysts of the type $\left[\left(\mathrm{bpaH}_{2}\right) \mathrm{Ru}(\mathrm{L})_{2}\right]\left(\mathrm{bpaH}_{4}\right.$ is $2,2^{\prime}$-bipyridine6,6'-diphosphonic acid; $\mathrm{L}$ is 4-picoline or isoquinoline). ${ }^{41}$ The calculated free energy of activation for $\mathrm{O}-\mathrm{O}$ bond formation via intramolecular atom-proton transfer (i-APT) for $\left[\left(\mathrm{bpaH}_{2}\right) \mathrm{Ru}(\mathrm{py})_{2}\right]$ (py is pyridine) is only $10.2 \mathrm{kcal} / \mathrm{mol}$, the lowest free energy of activation reported for this elementary step, to the best of our knowledge. For comparison, the calculated free energies of activation for $\mathrm{O}-\mathrm{O}$ bond formation via $\mathrm{I} 2 \mathrm{M}$ for $\left[(\mathrm{bda}) \mathrm{Ru}(\mathrm{isq})_{2}\right]$ and $[(\mathrm{bda}) \mathrm{Ru}(6-$ F-isq) 2 (isq is isoquinoline; 6-F-isq is 6-fluoroisoquinoline) are $13.2 \mathrm{kcal} / \mathrm{mol}$ and $12.6 \mathrm{kcal} / \mathrm{mol}$, respectively. ${ }^{46}$ With turnover frequencies (TOFs) in the hundreds per second, $\left[(\mathrm{bda}) \mathrm{Ru}(\mathrm{isq})_{2}\right]$ and its derivatives are the fastest water oxidation catalysts in the literature to be measured at low $\mathrm{pH}$, and have the highest reported rates for chemically-driven catalysis at any $\mathrm{pH}^{21,47}$ However, 
TOFs for water oxidation catalysis by $\left[\left(\mathrm{bpaH}_{2}\right) \mathrm{Ru}(\mathrm{L})_{2}\right]$ are below $10 \mathrm{~s}^{-1}$ because of slow oxidation of $\left[(\mathrm{bpa}) \mathrm{Ru}^{\mathrm{III}}(\mathrm{L})_{2}\right]^{-}$to $\left[(\mathrm{bpa}) \mathrm{Ru}^{\mathrm{IV}}(\mathrm{L})_{2}\right]$ or $\quad\left[(\mathrm{bpa}) \mathrm{Ru}^{\mathrm{IV}}(\mathrm{L})_{2}(\mathrm{OH})\right]^{-}$to $\left[(\mathrm{bpa}) \mathrm{Ru}^{\mathrm{V}}(\mathrm{L})_{2}(\mathrm{O})\right]^{-41} \cdot{ }^{41}$ In addition, oxidation of $\left[(\mathrm{bpa}) \mathrm{Ru}^{\mathrm{III}}(\mathrm{L})_{2}\right]^{-}$to $\left[(\mathrm{bpa}) \mathrm{Ru}^{\mathrm{IV}}(\mathrm{L})_{2}\right](\sim 1.6 \mathrm{~V}$ vs NHE) is not proton-coupled and water incorporation into the coordination sphere only occurs at $\left[(\mathrm{bpa}) \mathrm{Ru}^{\mathrm{IV}}(\mathrm{L})^{2}\right]$, resulting in a high overpotential for catalysis.<smiles>O=C(O)c1cccc(-c2cccc(C(=O)O)n2)n1</smiles>
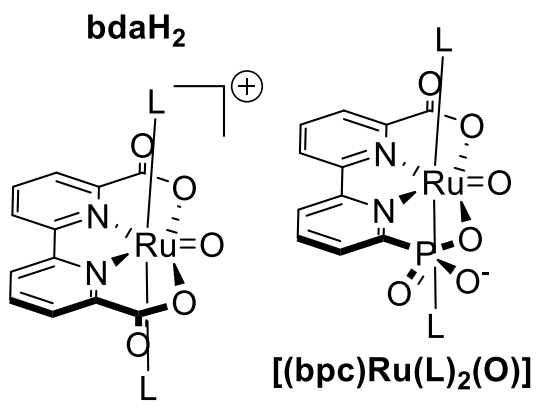<smiles>CCP(=O)(O)c1cccc(-c2cccc(C(=O)O)n2)n1</smiles>

$\left[(\mathrm{bda}) \operatorname{Ru}(\mathrm{L})_{2}(\mathrm{O})\right]^{+}$<smiles>O=P(O)(O)c1cccc(-c2cccc(P(=O)(O)O)n2)n1</smiles>
$\mathrm{bpaH}_{4}$

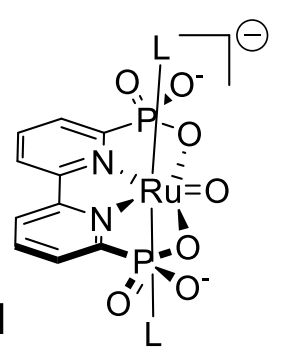

$\left[(\mathrm{bpa}) \operatorname{Ru}(\mathrm{L})_{2}(\mathrm{O})\right]^{-}$

Chart 1. Ligands 2,2'-bipyridine-6,6'-dicarboxylic acid (bdaH $\left.\mathrm{b}_{2}\right)$, 6'-phosphono-[2,2'bipyridine]-6-carboxylic acid $\left(\mathrm{bpH}_{2} \mathrm{cH}\right)$, and 2,2'-bipyridine-6,6'-diphosphonic acid $\left(\mathrm{bpaH}_{4}\right)$, and their corresponding ruthenium(V)-oxo complexes. $\mathrm{L}$ is a monodentate ligand, typically a 4picoline or isoquinoline.

We report here a single-site hybrid system that combines the best features of the $\left[(b d a) R u(L)_{2}\right]$ and the $\left[\left(\mathrm{bpaH}_{2}\right) \mathrm{Ru}(\mathrm{L})_{2}\right]$ systems: $\left[(\mathrm{bpHc}) \mathrm{Ru}(\mathrm{L})_{2}\right]\left(\mathrm{bpH}_{2} \mathrm{cH}\right.$ is 6'-phosphono-[2,2'-bipyridine]-6carboxylic acid, L is 4-picoline or isoquinoline). These new catalysts retain the base-assisted, low-activation-energy $i$-APT pathway for $\mathrm{O}-\mathrm{O}$ bond formation while also allowing water 
coordination at the $\mathrm{Ru}^{\mathrm{III}}$ state, leading to a significant reduction in overpotentials with respect to $\left[\left(\mathrm{bpaH}_{2}\right) \mathrm{Ru}(\mathrm{L})_{2}\right]$ as well as faster oxidations in the catalyst activation steps via intramolecular proton-coupled electron transfer $(i$-PCET). The combination of these features results in the fastest single-site catalysts reported in acidic solution to date with the hybrid systems outperforming both the $\left[\left(\mathrm{bpaH}_{2}\right) \mathrm{Ru}(\mathrm{L})_{2}\right]$ and the $\left[(\mathrm{bda}) \mathrm{Ru}(\mathrm{L})_{2}\right]$ "parent" compounds under identical conditions.

\section{Results and Discussion}

Synthesis and Characterization. The hybrid ligand precursor 6-carboxy-6'-phosphono-[2,2'bipyridin]-1-ium chloride $\left(\mathrm{bpH}_{2} \mathrm{cH} \cdot \mathrm{HCl}\right)$ was synthesized in 3 steps with $62 \%$ overall yield from the known compound 6'-bromo-[2,2'-bipyridine]-6-carboxylic acid, as shown in Figure S1. Following esterification of the acid in methanol, palladium-catalyzed coupling with diethylphosphonate converted the bromo to a phosphonic acid ester. Treatment with hydrochloric acid hydrolyzed both the phosphonate and carboxylate esters, providing the free protonated phosphonic-carboxylic acid $\mathrm{bpH}_{2} \mathrm{cH} \cdot \mathrm{HCl}$.

Ruthenium(II) complexes $\left[(\mathrm{bpHc}) \mathrm{Ru}(\mathrm{L})_{2}\right]$ were synthesized in $51 \%(\mathrm{~L}=4$-picoline $)$ and $86 \%$ ( $\mathrm{L}=$ isoquinoline) yield from $\mathrm{bpH}_{2} \mathrm{cH} \cdot \mathrm{HCl},\left[\mathrm{RuCl}_{2}\left(\mathrm{C}_{6} \mathrm{H}_{6}\right)\right]_{2}$, triethylamine, and the appropriate axial ligand. Refluxing $\left[\mathrm{RuCl}_{2}\left(\mathrm{C}_{6} \mathrm{H}_{6}\right)\right]_{2}$ with $\mathrm{bpH}_{2} \mathrm{cH} \cdot \mathrm{HCl}$ and excess triethylamine and 4-picoline or isoquinoline in methanol produced a dark solution, which was evaporated to dryness. The residue containing the triethylammonium salts $\left[\operatorname{HNEt}_{3}\right]\left[(\mathrm{bpc}) \mathrm{Ru}(\mathrm{L})_{2}\right]$ were then redissolved in aqueous $\mathrm{NaOH}$ and precipitated with acid.

Aerobic oxidation of $\left[(\mathrm{bpHc}) \mathrm{Ru}^{\mathrm{II}}(\mathrm{L})_{2}\right]$ produced ruthenium(III) complexes, which were isolated and characterized crystallographically. Solutions of $\left[(\mathrm{bpHc}) \mathrm{Ru}^{\mathrm{II}}(\mathrm{L})_{2}\right]$ are slowly oxidized in air, producing the ruthenium(III) complexes $\left[(\mathrm{bpc}) \mathrm{Ru}(\mathrm{L})_{2}\right]\left(\right.$ or $\left[(\mathrm{bpHc}) \mathrm{Ru}(\mathrm{L})_{2}\right]^{+}$at low $\left.\mathrm{pH}\right)$, 
and then uncharacterized further oxidized products. Cooling to $4{ }^{\circ} \mathrm{C}$ effected crystallization of the $\mathrm{Ru}^{\mathrm{III}}$ complexes. Figure $1($ left $)$ shows the $\left[(\mathrm{bpHc}) \mathrm{Ru}^{\mathrm{III}}(\mathrm{pic})_{2}\right]^{+}$cation with an adjacent water molecule, which is hydrogen-bonded to the phosphonic acid group. [(bpc)Ru $\left.{ }^{\text {III }}(\text { isq })_{2}\right]$ was crystallized as the neutral deprotonated complex at neutral $\mathrm{pH}$, shown in Figure 1 (right).

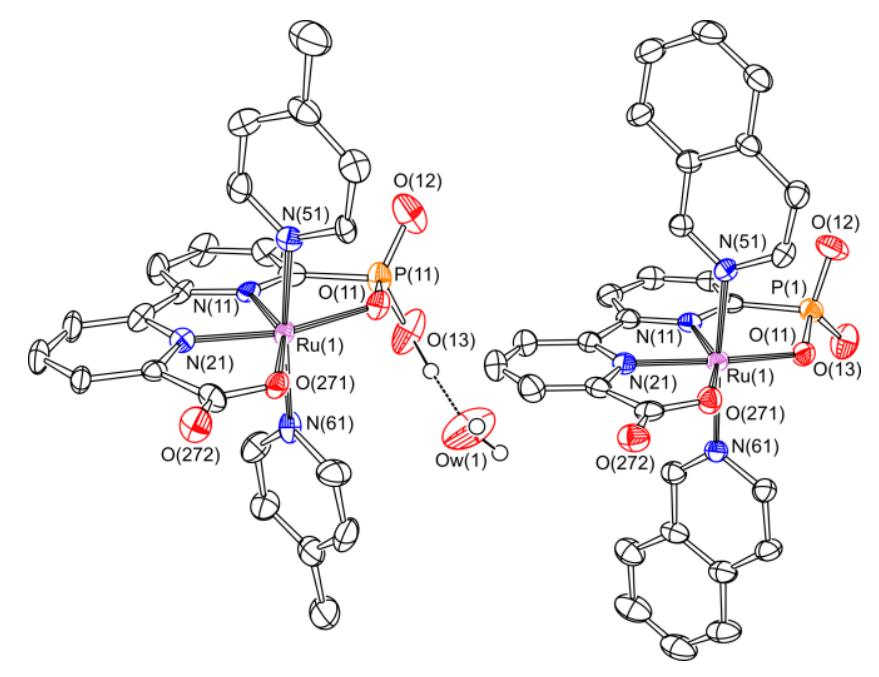

Figure 1. ORTEP structures for $\left[(\mathrm{bpHc}) \mathrm{Ru}^{\mathrm{III}}(\mathrm{pic})_{2}\right]\left[\mathrm{ClO}_{4}\right] \cdot \mathrm{H}_{2} \mathrm{O}$ (left $)$ and $\left[(\mathrm{bpc}) \mathrm{Ru}^{\mathrm{III}}(\mathrm{isq})_{2}\right]$ (right). Perchlorate ion and hydrogen atoms (except $\mathrm{OH}$ ) omitted for clarity. Ellipsoids at 50\%.

The major structural difference between the bpc-ruthenium(III) complexes and their diphosphonate and dicarboxylate counterparts is the decrease of the O-Ru-O angle from $\left[(\text { bda }) \mathrm{Ru}^{\mathrm{III}}(\mathrm{pic})_{2}\right]^{+} \quad\left(126.39(7)^{\circ}\right)$ and $\quad\left[(\mathrm{bda}) \mathrm{Ru}(\text { isq })_{2}\right]^{+} \quad\left(126.0(3)^{\circ}\right)^{23}$ to $\quad\left[(\mathrm{bpc}) \mathrm{Ru}^{\mathrm{III}}(\text { isq })_{2}\right]$ $\left(117.63(10)^{\circ}\right)$ to $\left[(\mathrm{bpa}) \mathrm{Ru}^{\mathrm{III}}(\mathrm{pic})_{2}\right]^{-}\left(112.09(6)^{\circ}\right){ }^{41}$ This is the result of the longer C-P and P-O bond distances in the phosphonate group compared to the $\mathrm{C}-\mathrm{C}$ and $\mathrm{C}-\mathrm{O}$ bond distances in the carboxylate group as well as the smaller C-P-O angle ( $\mathrm{sp}^{3}$ hybridization at $\left.\mathrm{P}\right)$ in the phosphonate group compared to the $\mathrm{C}-\mathrm{C}-\mathrm{O}$ angle $\left(\mathrm{sp}^{2}\right.$ hybridization at $\mathrm{C}$ ) in the carboxylate group. A comparison of the bond distances and $\mathrm{O}-\mathrm{Ru}-\mathrm{O}$ angle between $\left[(\mathrm{bpc}) \mathrm{Ru}(\mathrm{isq})_{2}\right]$ and $\left[(\mathrm{bda}) \mathrm{Ru}(\text { isq })_{2}\right]^{+}$is shown in Figure 2. Protonation of the uncoordinated P-O group causes a small contraction of the bound P-O from 1.563(3) $\AA$ in $\left[(\mathrm{bpc}) \mathrm{Ru}^{\mathrm{III}}(\text { isq })_{2}\right]$ to $1.537(5) \AA$ in 
$\left[(\mathrm{bpHc}) \mathrm{Ru}^{\mathrm{III}}(\mathrm{pic})_{2}\right]^{+}$and an elongation in the Ru-O bond from $2.012(2) \AA$ in $\left[(\mathrm{bpc}) \mathrm{Ru}^{\mathrm{III}}(\text { isq })_{2}\right]$ to $2.049(3) \AA\left[(\mathrm{bpHc}) \mathrm{Ru}^{\mathrm{III}}(\mathrm{pic})_{2}\right]^{+}$. The $\mathrm{Ru}-\mathrm{N}_{\text {bpy }}$ bond is also $0.04 \AA$ longer in the protonated complex. As a result, the O-Ru-O angle is widened in $\left[(\mathrm{bpHc}) \mathrm{Ru}^{\mathrm{III}}(\mathrm{pic})_{2}\right]^{+}$to $120.05(17)^{\circ}$.

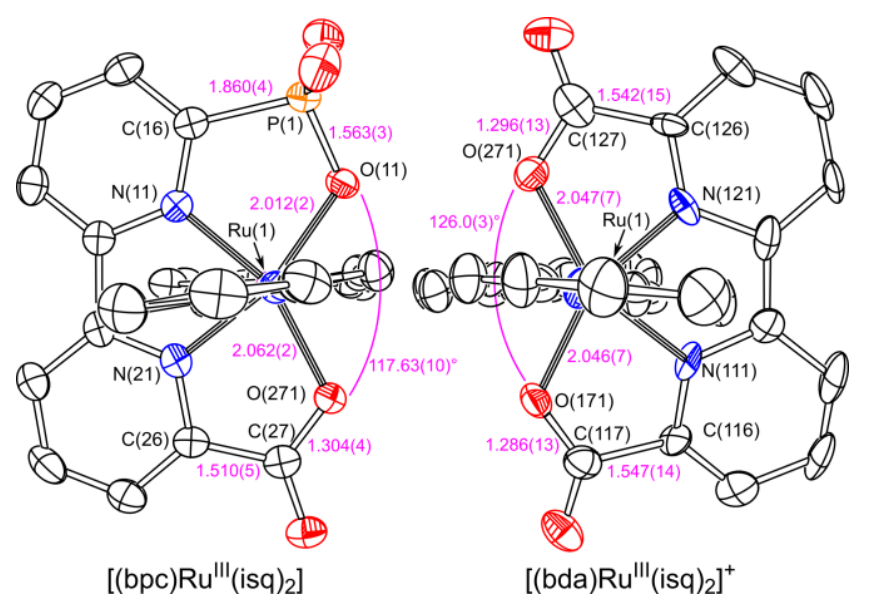

Figure 2. ORTEP structures showing a top-down view of $\left[(\mathrm{bpc}) \mathrm{Ru}^{\mathrm{III}}(\mathrm{isq})_{2}\right]$ (left) and $\left[(\text { bda }) \mathrm{Ru}^{\mathrm{III}}(\text { isq })_{2}\right]^{+}(\text {right })^{23}$ with selected bond distances and angles. Ellipsoids shown at $50 \%$ probability. Hydrogen atoms, anion, and co-crystallized water molecules omitted for clarity.

Electrochemical Characterization and Catalytic Water Oxidation. Electrochemical measurements showed that while the $\mathrm{Ru}^{\text {III/II }}$ oxidation potential for the bpc complexes are similar to those of the bpa complexes, the $\mathrm{Ru}^{\mathrm{IV} / \mathrm{III}}$ couple and the onset for water oxidation catalysis for the bpc complexes are both about $200 \mathrm{mV}$ lower in potential. Figure 3 shows cyclic voltammograms $(\mathrm{CVs})$ and square wave voltammograms ( $\mathrm{SWVs})$ for $\left[(\mathrm{bpHc}) \mathrm{Ru}(\mathrm{pic})_{2}\right]\left[\mathrm{ClO}_{4}\right]$ and $\left[\left(\mathrm{bpaH}_{2}\right) \mathrm{Ru}(\mathrm{pic})_{2}\right]$ at $\mathrm{pH} 1\left(0.10 \mathrm{M} \mathrm{HClO}_{4}\right)$. The $\mathrm{Ru}^{\mathrm{III} / \mathrm{II}}$ couples for the bpc complexes are reversible and similar in potential to the bpa complexes, appearing at $0.65 \mathrm{~V}$ for $\left[(\mathrm{bpHc}) \mathrm{Ru}(\mathrm{pic})_{2}\right]$ and $0.68 \mathrm{~V}$ for $\left[(\mathrm{bpHc}) \mathrm{Ru}(\mathrm{isq})_{2}\right]$ (all potentials are reported vs NHE) ${ }^{48}$ The $\mathrm{Ru}^{\mathrm{IV} / I I I}$ couple appears at $1.40 \mathrm{~V}$ for $\left[(\mathrm{bpHc}) \mathrm{Ru}(\text { pic })_{2}\right]$ and $1.41 \mathrm{~V}$ for $\left[(\mathrm{bpHc}) \mathrm{Ru}(\text { isq })_{2}\right]$ and is not chemically reversible on the $\mathrm{CV}$ timescale. 
Immediately following the $\mathrm{Ru}^{\mathrm{IV} / \mathrm{III}}$ wave is a sharp increase in current corresponding to catalytic water oxidation. The onset of catalysis at approximately $1.50 \mathrm{~V}$ corresponds to an overpotential of $330 \mathrm{mV}$ at $\mathrm{pH} 1$. SWV finds the $\mathrm{Ru}^{\mathrm{V} / \mathrm{IV}}$ potential at $1.61 \mathrm{~V}$, but this value is approximate due to the overlapping catalytic wave. A notable feature is the substantial increase in catalytic current in $\left[(\mathrm{bpHc}) \mathrm{Ru}(\mathrm{pic})_{2}\right]$ compared to $\left[\left(\mathrm{bpaH}_{2}\right) \mathrm{Ru}(\mathrm{pic})_{2}\right]$, under identical conditions. Similar behavior is observed for the isq congeners, which were analyzed in $0.10 \mathrm{M}$ $\mathrm{HNO}_{3}$ due to their poor solubility in $\mathrm{HClO}_{4}$ (see Figure S8 and Figure S9). A plot of background-corrected catalytic current $\left(\mathrm{i}_{\text {cat }}\right)$ at $1.60 \mathrm{~V}$ vs $\left[(\mathrm{bpHc}) \mathrm{Ru}(\mathrm{pic})_{2}\right]$ catalyst concentration showed a linear dependence and a plot of $-\log \left(-\mathrm{i}_{\text {cat }}\right)$ vs $-\log$ [catalyst] showed a slope close to 1 (see Figure S11), consistent with stopped-flow measurements and the first-order single-site mechanism proposed below. 

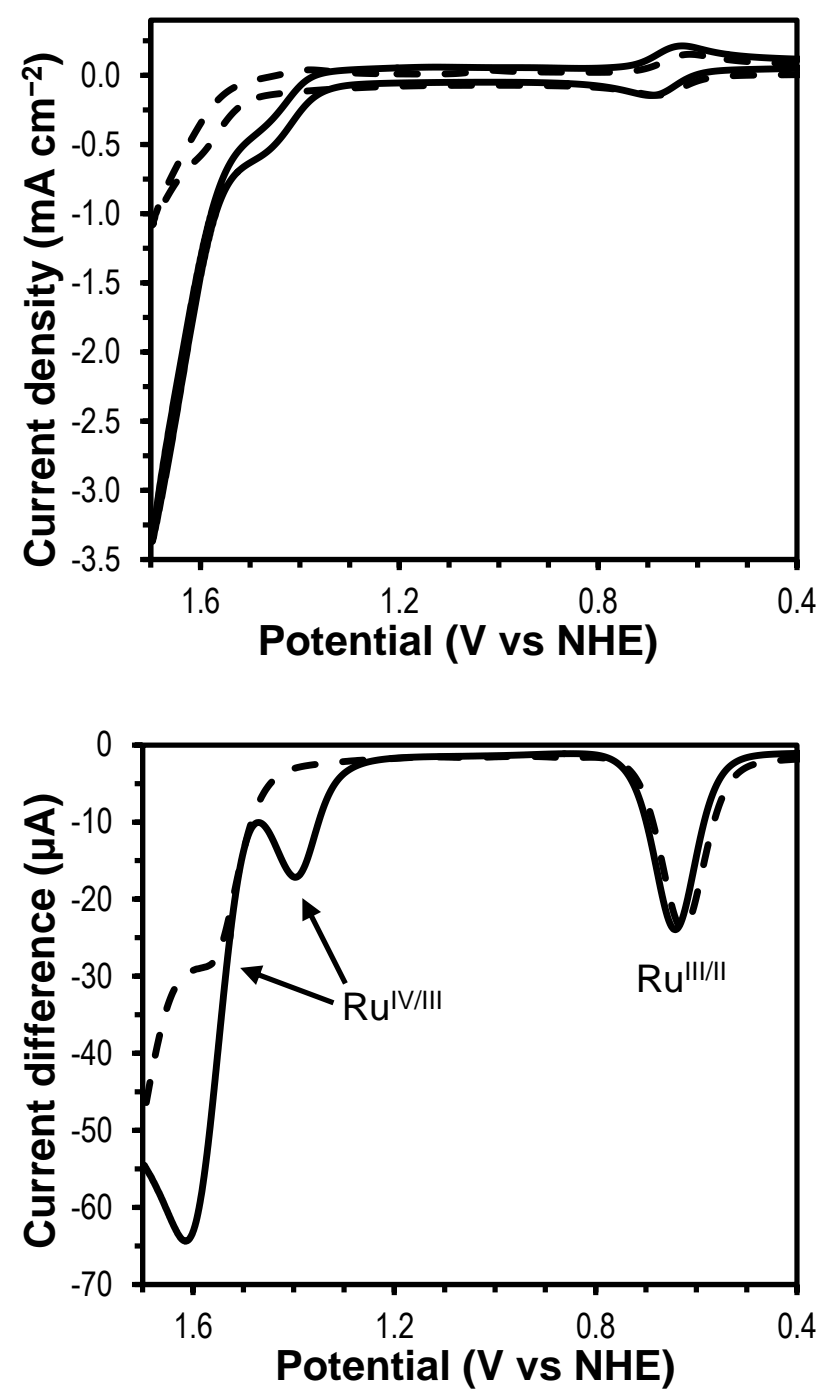

Figure 3. Cyclic (top) and square wave (bottom) voltammograms for $\left[(\mathrm{bpHc}) \mathrm{Ru}(\mathrm{pic})_{2}\right]\left[\mathrm{ClO}_{4}\right]$ (solid lines) and [( $\left.\left(\mathrm{ppaH}_{2}\right) \mathrm{Ru}(\mathrm{pic})_{2}\right]$ (dashed lines). $1.0 \mathrm{mM}$ complex in $0.10 \mathrm{M} \mathrm{HClO}_{4}, \mathrm{pH} 1$.

Kinetics of $\left[(\mathrm{bpHc}) \mathrm{Ru}(\mathrm{L})_{2}\right]$-Mediated Water Oxidation. Stopped-flow kinetic measurements were used to determine the rate law for the cerium(IV)-driven catalytic water oxidation by the bpc-Ru catalysts. Aqueous solutions of catalyst with concentrations $6 \mu \mathrm{M}$ to $150 \mu \mathrm{M}$ were mixed with $1.5 \mathrm{mM}$ ceric ammonium nitrate $(\mathrm{CAN}, \mathrm{E}=1.6 \mathrm{~V})^{49}$ in $0.20 \mathrm{M} \mathrm{HNO}_{3}$ and the consumption of cerium(IV) was monitored using its absorption at $360 \mathrm{~nm}$. Under these 
conditions, the cerium(IV) was consumed with a first-order dependence, and the rate was found to be first order in catalyst as well, as shown in equation (1) (see Figure S12 and Figure S13).

$$
\frac{-d\left[C e^{I V}\right]}{d t}=k_{1,1}[R u]\left[C e^{I V}\right]
$$

The rate law suggests that the rate-determining step (RDS) is an oxidation of the catalyst by cerium(IV). The experimental rate constants $k_{1,1}$ for this step are $1.2 \times 10^{5} \mathrm{M}^{-1} \mathrm{~s}^{-1}$ and $1.6 \times 10^{5}$ $\mathrm{M}^{-1} \mathrm{~s}^{-1}$ for $\left[(\mathrm{bpHc}) \mathrm{Ru}(\mathrm{pic})_{2}\right]\left[\mathrm{ClO}_{4}\right]$ and $\left[(\mathrm{bpHc}) \mathrm{Ru}(\mathrm{isq})_{2}\right]$, respectively. This constitutes a $10^{2}-$ fold improvement over the bpa catalysts and a $\sim 10$-fold improvement over the bda catalysts, ${ }^{50}$ supporting the notion that the water binding and more accessible $i$-PCET oxidations of the bpc complexes result in faster oxidations.

According to the experimental rate law, the turnover frequency $(\mathrm{TOF}=$ $\left(d\left[\mathrm{O}_{2}\right] / d t\right) /[$ catalyst] $)$ for the bpc catalysis should be proportional to $\left[\mathrm{Ce}^{\mathrm{IV}}\right]$ and up to $107 \mathrm{~s}^{-1}$ was reached for $100 \mu \mathrm{M}\left[(\mathrm{bpHc}) \mathrm{Ru}(\text { isq })_{2}\right]$ with $1.5 \mathrm{mM}$ cerium. For comparison, TOF $=65 \mathrm{~s}^{-1}$ for $100 \mu \mathrm{M}\left[(\mathrm{bda}) \mathrm{Ru}(\text { isq })_{2}\right]$ and TOF $=0.77 \mathrm{~s}^{-1}$ for $100 \mu \mathrm{M}\left[\left(\mathrm{bpaH}_{2}\right) \mathrm{Ru}(\text { isq })_{2}\right]$ with $2.0 \mathrm{mM}$ cerium. Table 1 shows a comparison of TOFs under various conditions for the three families of catalysts.

Oxygen production was verified in separate experiments using gas chromatographic analysis of the headspace after reactions in closed vessels and the yields were $93 \%$ with $\left[(\mathrm{bpHc}) \mathrm{Ru}(\mathrm{pic})_{2}\right]\left[\mathrm{ClO}_{4}\right]$ and $88 \%$ with $\left[(\mathrm{bpHc}) \mathrm{Ru}(\mathrm{isq})_{2}\right]$ with respect to $\mathrm{Ce}^{\mathrm{IV}}$ used. High yields were also recorded by pressure measurements with CAN concentrations up to $0.365 \mathrm{M}$, however these conditions actually led to lower turnover frequencies for $\left[(\mathrm{bpHc}) \mathrm{Ru}(\mathrm{L})_{2}\right]$, revealing an inverse relationship between the rate and $\left[\mathrm{Ce}^{\mathrm{IV}}\right]$ under these conditions. This is indicative of an inhibitory reaction pathway involving the cerium. Indeed, experimental turnover numbers with 
Table 1. Kinetic data from stopped-flow experiments for cerium(IV)-driven water oxidation catalysis mediated by ruthenium complexes of carboxylate- and phosphonate- substituted bipyridines.

\begin{tabular}{|c|c|c|c|c|c|c|}
\hline Catalyst & $\begin{array}{l}k_{1,1}^{\dagger} \\
\left(\mathbf{M}^{-1} \mathbf{s}^{-1}\right)\end{array}$ & $\begin{array}{l}\text { [catalyst] } \\
(\mu \mathrm{M})\end{array}$ & $\begin{array}{l}k_{\text {obs }}^{\dagger} \\
\left(s^{-1}\right)\end{array}$ & $\begin{array}{l}\mathbf{T O F}^{*} \\
\left(\mathbf{s}^{-1}\right)\end{array}$ & TON & conditions \\
\hline \multirow{2}{*}[(\mathrm{bpHc})\mathrm{Ru}(\text{isq})_{2}]{} & \multirow{2}{*}{$1.6 \times 10^{5}$} & 100 & 28.6 & 107 & 3.8 & $\mathrm{a}$ \\
\hline & & 50 & 12.7 & 95 & 7.5 & $\mathrm{a}$ \\
\hline \multirow{2}{*}[(\mathrm{bpHc})\mathrm{Ru}(\mathrm{pic})_{2}]{$\left[\mathrm{ClO}_{4}\right]$} & \multirow{2}{*}{$1.2 \times 10^{5}$} & 100 & 15.4 & 58 & 3.8 & $\mathrm{a}$ \\
\hline & & 50 & 6.01 & 45 & 7.5 & $\mathrm{a}$ \\
\hline \multirow{2}{*}[(\mathrm{bpaH}_{2})\mathrm{Ru}(\mathrm{isq})_{2}]{} & \multirow{2}{*}{$1.9 \times 10^{3}$} & 100 & 0.154 & 0.77 & 5.0 & $\mathrm{~b}$ \\
\hline & & 50 & 0.0972 & 0.97 & 10 & $\mathrm{~b}$ \\
\hline \multirow{2}{*}[(\mathrm{bpaH}_{2})\mathrm{Ru}(\mathrm{pic})_{2}]{} & \multirow{2}{*}{$1.6 \times 10^{3}$} & 100 & 0.129 & 0.65 & 5.0 & $\mathrm{~b}$ \\
\hline & & 50 & 0.0818 & 0.82 & 10 & $\mathrm{~b}$ \\
\hline \multirow{2}{*}{ [(bda)Ru(isq) $)_{2}$} & \multirow{2}{*}{$6.7 \times 10^{4}$} & 100 & 12.9 & 65 & 5.0 & $\mathrm{c}$ \\
\hline & & 50 & 6.36 & 64 & 10 & $\mathrm{c}$ \\
\hline \multirow{2}{*}[(\mathrm{bda})\mathrm{Ru}(\mathrm{pic})_{2}]{} & \multirow{2}{*}{$1.8 \times 10^{4}$} & 100 & 3.94 & 20 & 5.0 & $\mathrm{c}$ \\
\hline & & 50 & 1.11 & 11 & 10 & $\mathrm{c}$ \\
\hline \multicolumn{7}{|c|}{$\begin{array}{l}\mathrm{a}=1.5 \mathrm{mM} \text { CAN }, 0.10 \mathrm{M} \mathrm{HNO}_{3} \\
\mathrm{~b}=2.0 \mathrm{mM} \text { CAN, } 0.10 \mathrm{M} \mathrm{HNO}_{3}{ }^{41} \\
\mathrm{c}=2.0 \mathrm{mM} \mathrm{CAN}, 0.10 \mathrm{M} \mathrm{HClO}_{4} \text { with } 10 \% \mathrm{CH}_{3} \mathrm{CN}^{50} \\
k_{\text {obs }}=-\left(d\left[\mathrm{Ce}^{\mathrm{IV}}\right] / d \mathrm{t}\right) /([\mathrm{Ce}])=k_{1,1}[\text { Catalyst }] \\
\mathrm{TOF}=\left(d\left[\mathrm{O}_{2}\right] / d \mathrm{t}\right) /([\text { Catalyst }])=\left(k_{\mathrm{obs}}\left[\mathrm{Ce}^{\mathrm{IV}}\right]\right) /(4[\text { Catalyst }])\end{array}$} \\
\hline
\end{tabular}

cerium(IV) were limited to 67 for $\left[(\mathrm{bpHc}) \mathrm{Ru}(\text { isq })_{2}\right]$ and 28 for $\left[(\mathrm{bpHc}) \mathrm{Ru}(\mathrm{pic})_{2}\right][\mathrm{ClO} 4]$. We suppose this may be due to interaction between the cerium and the deprotonated phosphonate ligand, ${ }^{51-54}$ blocking its pendant base function (vide infra). Results of catalytic cerium(IV)-driven experiments showed the catalysts to be fast and efficient, but raised questions about their durability. 
To determine whether the low TON are general for bpc catalysts or are the result of specific interactions with cerium, we explored $\left[\mathrm{Co}^{\mathrm{III}}\left(\mathrm{OH}_{2}\right)_{6}\right]^{3+}$ as an alternative oxidant $(\mathrm{E}=\mathrm{ca} .1 .9 \mathrm{~V}$ vs NHE). ${ }^{55,56}$ The rate of cobalt(III)-driven catalysis was limited by slow electron transfer to the $\mathrm{Co}^{\mathrm{III}}$, with the TOF reaching only $0.44 \mathrm{~s}^{-1}$, compared to $5.6 \mathrm{~s}^{-1}$ under similar conditions with $\mathrm{Ce}^{\mathrm{IV}}$. Cobalt(III)'s sluggish electron $\operatorname{transfer}^{56}$ was verified by stopped-flow experiments observing a slow reaction for electron transfer from $\left[\mathrm{Ru}\left(4-\mathrm{CF}_{3}-\mathrm{bpy}\right)_{3}\right]^{2+}$, which has a $\mathrm{Ru}^{\mathrm{III} / \mathrm{II}}$ potential similar to the $\mathrm{Ru}^{\mathrm{V} / \mathrm{IV}}$ potential of the bpc catalysts (see Supporting Information), but a much faster self-exchange rate than $\left[\mathrm{Co}^{\mathrm{III} / \mathrm{II}}\left(\mathrm{OH}_{2}\right)_{6}\right]^{3+/ 2+}$ or the catalyst. ${ }^{57}$ On the other hand, the turnover number was greatly improved with cobalt(III), reaching up to 1600 for $\left[(\mathrm{bpHc}) \mathrm{Ru}(\mathrm{isq})_{2}\right]$ (see Figure S14), compared to $\sim 50$ with cerium(IV) under similar conditions. Thus, the previously observed inhibitory behavior and low TON are specific to cerium. [(bpHc) $\left.\mathrm{Ru}(\mathrm{isq})_{2}\right]$ and $\left[(\mathrm{bda}) \mathrm{Ru}(\mathrm{isq})_{2}\right]$ perform similarly in cobalt-driven reactions, with the former reaching a higher TON (see Figure S16). These results show that the bpc catalysts can achieve relatively high TON. Together, the electrochemical, cerium-driven, and cobalt-driven experiments indicate that the bpc single-site catalysts are both fast and durable.

Water Oxidation Mechanism. The mechanism of water oxidation by $\left[(\mathrm{bpHc}) \mathrm{Ru}(\mathrm{L})_{2}\right]$, was established by complementing the aforementioned kinetic studies with DFT calculations. Experimental studies of higher oxidation state intermediates were stymied by the proximity and overlapping signals of the $\mathrm{Ru}^{\mathrm{IV} / I I I}$ couple, the $\mathrm{Ru}^{\mathrm{V} / \mathrm{IV}}$ couple, and the catalytic water oxidation wave. Consequently, the most favorable pathway for $\mathrm{O}_{2}$ production was probed computationally and is shown in Figure 4. The mechanism can be separated into a few phases that are common to all water oxidation catalysts: (1) oxidative activation of the catalyst, (2) O-O bond formation, (3) oxidation of hydroperoxide/peroxide intermediates, and (4) $\mathrm{O}_{2}$ evolution. 
Oxidative activation of the catalysts. Beginning from $\left[(\mathrm{bpHc}) \mathrm{Ru}^{\mathrm{II}}(\mathrm{L})_{2}\right]$, the first step towards catalysis is oxidation to ruthenium(III). The calculated redox potential for the couple $\left[(\mathrm{bpHc}) \mathrm{Ru}^{\mathrm{III}}(\mathrm{py})_{2}\right]^{+} /\left[(\mathrm{bpHc}) \mathrm{Ru}^{\mathrm{II}}(\mathrm{py})_{2}\right]^{58}$ at $\mathrm{pH} 0$ is $0.53 \mathrm{~V}$, close to the experimental value of 0.66 $\mathrm{V}$ for $\left[(\mathrm{bpHc}) \mathrm{Ru}^{\mathrm{III}}(\mathrm{pic})_{2}\right]^{+} /\left[(\mathrm{bpHc}) \mathrm{Ru}^{\mathrm{II}}(\mathrm{pic})_{2}\right]$. The $\mathrm{p} K_{\mathrm{a}}$ of the phosphonic acid in $\left[(\mathrm{bpHc}) \mathrm{Ru}^{\mathrm{III}}(\mathrm{pic})_{2}\right]^{+}$is about 1.0 (calc 1.03), as shown in the Pourbaix diagram (Figure S11). Above $\mathrm{pH} 1$, the $\mathrm{Ru}^{\mathrm{III} / \mathrm{II}}$ potential decreases with increasing $\mathrm{pH}$ until the $\mathrm{p} K_{\mathrm{a}}$ of $\left[(\mathrm{bpHc}) \mathrm{Ru}^{\mathrm{II}}(\mathrm{pic})_{2}\right]$ is reached (exp. $\sim 4$, calc. $=3.8)$.

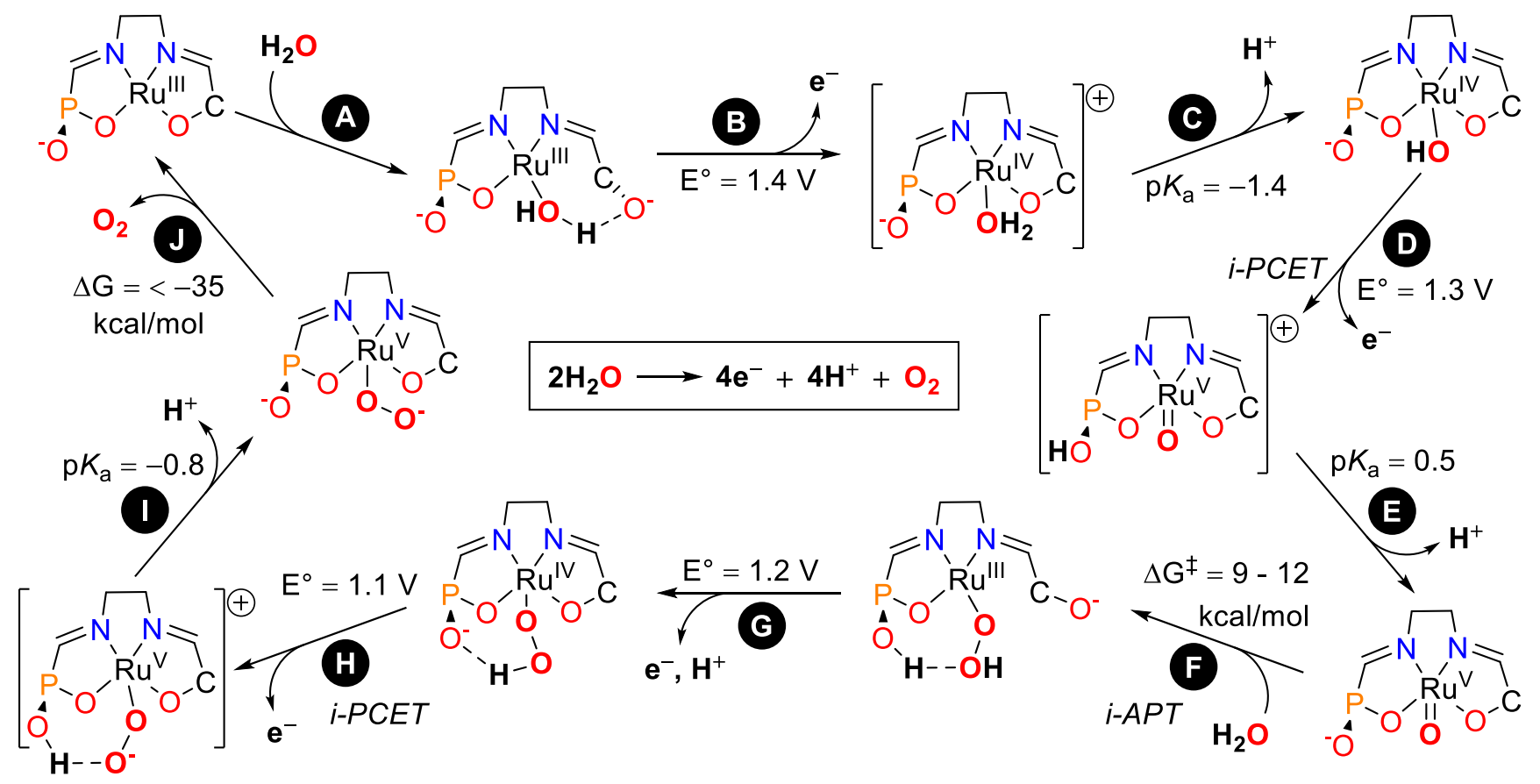

Figure 4. Proposed mechanism for water oxidation by $\left[(\mathrm{bpHc}) \mathrm{Ru}(\mathrm{L})_{2}\right]$ catalysts at $\mathrm{pH} 1$, showing only the immediate coordination environment in the plane of the active site and transient intermediates in brackets $\left(\mathrm{bpH}_{2} \mathrm{cH}\right.$ is 6'-phosphono-[2,2'-bipyridine]-6-carboxylic acid, $\mathrm{L}$ is 4-picoline or isoquinoline).

The steps preceding $\mathrm{O}-\mathrm{O}$ bond formation require binding of a water molecule and oxidative activation to reach a reactive metal-oxo. The bound water molecule also serves to moderate 
subsequent oxidation potentials by losing protons, stabilizing the more oxidized complexes and reducing the overall charge. Our previous generation single-site catalyst, $\left[\left(\mathrm{bpaH}_{2}\right) \mathrm{Ru}(\mathrm{L})_{2}\right]$, binds a water molecule at the ruthenium(IV) state, and oxidation of $\left[(\mathrm{bpa}) \mathrm{Ru}^{\mathrm{III}}(\mathrm{L})_{2}\right]^{-}$to $\left[(\mathrm{bpa}) \mathrm{Ru}^{\mathrm{IV}}(\mathrm{L})_{2}\right]$ is $\mathrm{pH}$-independent, taking place at $\sim 1.6 \mathrm{~V} .^{41}$ For the well-known bimolecular catalysts $\left[(\mathrm{bda}) \mathrm{Ru}(\mathrm{L})_{2}\right]$, this water binding occurs at $\left[(\mathrm{bda}) \mathrm{Ru}^{\mathrm{III}}(\mathrm{L})_{2}\right]^{+}$to generate $\left[\left(\kappa^{3}-\right.\right.$ bda) $\left.\mathrm{Ru}^{\mathrm{III}}(\mathrm{L})_{2}\left(\mathrm{OH}_{2}\right)\right]^{+}$where one of the carboxylate groups is unbound. A 20-electron $\left[(\mathrm{bda}) \mathrm{Ru}^{\mathrm{II}}(\mathrm{L})_{2}\left(\mathrm{OH}_{2}\right)\right]$ complex has been proposed, ${ }^{21,59,60}$ however our calculations find this to be $\sim 10 \mathrm{kcal} / \mathrm{mol}$ higher in energy relative to $\left[(\mathrm{bda}) \mathrm{Ru}^{\mathrm{II}}(\mathrm{L})_{2}\right]$. In $\left[\left(\kappa^{3}-\mathrm{bda}\right) \mathrm{Ru}^{\mathrm{III}}(\mathrm{py})_{2}\left(\mathrm{OH}_{2}\right)\right]^{+}$, the free carboxylate is hydrogen-bonded to the coordinated water molecule, and proton transfer from the water molecule to the carboxylate to form $\left[\left(\kappa^{3}-b d a H\right) \mathrm{Ru}^{\text {IIII }}(\mathrm{py})_{2}(\mathrm{OH})\right]^{+}$is facile with an equilibrium constant $K_{\mathrm{PT}}=1.07$. As a result, oxidation of $\left[\left(\kappa^{3}-\mathrm{bdaH}\right) \mathrm{Ru}^{\mathrm{III}}(\mathrm{py})_{2}(\mathrm{OH})\right]^{+}$to sevencoordinate $\left[(\mathrm{bda}) \mathrm{Ru}^{\mathrm{IV}}(\mathrm{py})_{2}(\mathrm{OH})\right]^{+}$is facile and $\mathrm{pH}$-dependent.

Similar water-binding behavior is observed here for $\left[(\mathrm{bpc}) \mathrm{Ru}^{\mathrm{III}}(\mathrm{py})_{2}\right]$ (step A in Figure 4), but the equilibrium favors $\left[\left(\kappa^{3}-\right.\right.$ bpc $\left.) \mathrm{Ru}^{\mathrm{III}}(\mathrm{py})_{2}\left(\mathrm{OH}_{2}\right)\right]$ over $\left[\left(\kappa^{3}-\mathrm{bpcH}\right) \mathrm{Ru}^{\mathrm{III}}(\mathrm{py})_{2}(\mathrm{OH})\right]$ with $K_{\mathrm{PT}}=$ 0.15 . This is consistent with the more sluggish $\mathrm{Ru}^{\mathrm{IV} / I I I}$ couple for $\left[(\mathrm{bpHc}) \mathrm{Ru}(\mathrm{L})_{2}\right]$ observed by voltammetry compared to that of $\left[(b d a) R u(L)_{2}\right]$. The calculated potential for oxidation of $\left[\left(\kappa^{3}-\right.\right.$ $\left.\mathrm{bpcH}) \mathrm{Ru}^{\mathrm{III}}(\mathrm{py})_{2}(\mathrm{OH})\right]$ to seven-coordinate $\left[(\mathrm{bpHc}) \mathrm{Ru}^{\mathrm{IV}}(\mathrm{py})_{2}(\mathrm{OH})\right]^{+}$is $1.15 \mathrm{~V}$ while that of $\left[\left(\kappa^{3}-\right.\right.$ bpc) Ru $\left.{ }^{\mathrm{III}}(\mathrm{py})_{2}\left(\mathrm{OH}_{2}\right)\right]$ to seven-coordinate $\left[(\mathrm{bpc}) \mathrm{Ru}^{\mathrm{IV}}(\mathrm{py})_{2}\left(\mathrm{OH}_{2}\right)\right]^{+}$is $1.37 \mathrm{~V}$ (step B), closer to the experimental value of $1.4 \mathrm{~V}$. The calculated $\mathrm{p} K_{\mathrm{a}}$ values for $\left[(\mathrm{bpHc}) \mathrm{Ru}^{\mathrm{IV}}(\mathrm{py})_{2}(\mathrm{OH})\right]^{+}$and $\left[(\mathrm{bpc}) \mathrm{Ru}^{\mathrm{IV}}(\mathrm{py})_{2}\left(\mathrm{OH}_{2}\right)\right]^{+}$are -0.08 and -1.41 , respectively, and deprotonation ultimately provides seven-coordinate $\left[(\mathrm{bpc}) \mathrm{Ru}^{\mathrm{IV}}(\mathrm{py})_{2}(\mathrm{OH})\right]$, regardless of the oxidation pathway (step C).

The final step in the oxidative activation process is a PCET oxidation from $\left[(\mathrm{bpc}) \mathrm{Ru}^{\mathrm{IV}}(\mathrm{py})_{2}(\mathrm{OH})\right]$ to $\left[(\mathrm{bpc}) \mathrm{Ru}^{\mathrm{V}}(\mathrm{py})_{2}(\mathrm{O})\right]$. The phosphate arm of the $\mathrm{bpc}^{3-}$ ligand acts as the 
initial proton acceptor in an intramolecular PCET process $(i$-PCET), with the potential for oxidation of $\left[(\mathrm{bpc}) \mathrm{Ru}^{\mathrm{IV}}(\mathrm{py})_{2}(\mathrm{OH})\right]$ to $\left[(\mathrm{bpHc}) \mathrm{Ru}^{\mathrm{V}}(\mathrm{py})_{2}(\mathrm{O})\right]^{+}$calculated as $1.28 \mathrm{~V}$ (step D). The low potential is consistent with the overlapping waves observed electrochemically. The calculated $\mathrm{p} K_{\mathrm{a}}$ for $\left[(\mathrm{bpHc}) \mathrm{Ru}^{\mathrm{V}}(\mathrm{py})_{2}(\mathrm{O})\right]^{+}$is 0.45 and proton transfer to the bulk follows to generate $\left[(\mathrm{bpc}) \mathrm{Ru}^{\mathrm{V}}(\mathrm{py})_{2}(\mathrm{O})\right]$, the active form of the catalyst (step E).

\section{O-O bond formation.}

While the kinetic data does not definitively establish the nature of the O-O bond forming step, when combined with transition state (TS) calculations, a strong support for single-site WNA catalysis emerges. Selected free energies of activation from DFT calculations are listed in Table 2, and the WNA and I2M TS structures for $\left[(\mathrm{bpc}) \mathrm{Ru}^{\mathrm{V}}(\text { isq })_{2}(\mathrm{O})\right]$ are shown in Figure 5. The cerium(IV)-driven experiments down to $6 \mu \mathrm{M}$ catalyst exhibit a first-order dependence on both catalyst and cerium(IV). Electrochemical experiments also find a first-order dependence on catalytic current with respect to catalyst concentration, shown in Figure S11. Sun and coworkers have shown that small changes in geometry can effect a change in mechanism. ${ }^{61}$ It is reasonable based on the geometrical differences discussed above (Figure 2) to anticipate a slightly higher barrier for intermolecular O-O coupling for the bpc catalysts compared to the bda catalysts. This is corroborated by comparison of the calculated I2M transition state energies for $\left[(\mathrm{bpc}) \mathrm{Ru}^{\mathrm{V}}(\text { isq })_{2}(\mathrm{O})\right]$ and $\left[(\mathrm{bda}) \mathrm{Ru}^{\mathrm{V}}(\text { isq })_{2}(\mathrm{O})\right]^{+}$, which are $16.5 \mathrm{kcal} / \mathrm{mol}$ and $13.2 \mathrm{kcal} / \mathrm{mol}$, respectively. Considering that $\left[(\mathrm{bda}) \mathrm{Ru}(\mathrm{isq})_{2}\right]$ and $\left[(\mathrm{bda}) \mathrm{Ru}(\mathrm{pic})_{2}\right]$ exhibit second-order behavior below $7 \mu \mathrm{M}$ and $69 \mu \mathrm{M}$, respectively, ${ }^{50}$ and that the bpc analogues have much higher rate constants for the oxidation step $\left(k_{1,1}\right)$, we would expect to observe second-order behavior for the bpc catalysts were a bimolecular step involved, which is not the case. Furthermore, calculated barriers for the $i$-APT step of the WNA mechanism predict this to be the favored pathway for the 
bpc catalysts. The barriers for nucleophilic attack of a water molecule on $\left[(\mathrm{bpc}) \mathrm{Ru}^{\mathrm{V}}(\mathrm{py})_{2}(\mathrm{O})\right]$ and $\left[(\mathrm{bpc}) \mathrm{Ru}^{\mathrm{V}}(\mathrm{isq})_{2}(\mathrm{O})\right]$ with concomitant proton-transfer to the phosphonate, which decoordinates, to generate $\left[\left(\kappa^{3}-\mathrm{bpHc}\right) \mathrm{Ru}^{\mathrm{III}}(\mathrm{L})_{2}(\mathrm{OOH})\right]($ step F) are $11.7 \mathrm{kcal} / \mathrm{mol}$ and $9.1 \mathrm{kcal} / \mathrm{mol}$, respectively, similar to the $10.2 \mathrm{kcal} / \mathrm{mol}$ barrier calculated for $\left[(\mathrm{bpa}) \mathrm{Ru}^{\mathrm{V}}(\mathrm{py})_{2}(\mathrm{O})\right]^{-41}{ }^{41}$ The oxo-oxo coupling barriers are significantly higher $\left(21.0 \mathrm{kcal} / \mathrm{mol}\right.$ and $16.5 \mathrm{kcal} / \mathrm{mol}$ for $\left[(\mathrm{bpc}) \mathrm{Ru}^{\mathrm{V}}(\mathrm{py})_{2}(\mathrm{O})\right]$ and $\left[(\mathrm{bpc}) \mathrm{Ru}^{\mathrm{V}}(\mathrm{isq})_{2}(\mathrm{O})\right]$, respectively), although they are significantly lower than that for $\left[(\mathrm{bpa}) \mathrm{Ru}^{\mathrm{V}}(\mathrm{py})_{2}(\mathrm{O})\right]^{-}$. In contrast, for $\left[(\mathrm{bda}) \mathrm{Ru}^{\mathrm{V}}(\mathrm{isq})_{2}(\mathrm{O})\right]^{+}$, the single-site APT pathway with proton transfer to an external water molecule is much less favorable $\left(\Delta \mathrm{G}^{\ddagger}=29.8 \mathrm{kcal} / \mathrm{mol}\right)$ than the bimolecular I2M $\left(\Delta \mathrm{G}^{*}=13.2 \mathrm{kcal} / \mathrm{mol}\right)$. A difference of $3.2 \mathrm{kcal} / \mathrm{mol}$ in free energies of activation for the O-O coupling step between $\left[(\text { bda }) \mathrm{Ru}^{\mathrm{v}}(\text { isq })_{2}(\mathrm{O})\right]^{+}\left(\Delta \mathrm{G}^{\ddagger}=13.2 \mathrm{kcal} / \mathrm{mol}\right)$ and $\left[(\mathrm{bpc}) \mathrm{Ru}^{\mathrm{V}}(\mathrm{isq})_{2}(\mathrm{O})\right]\left(\Delta \mathrm{G}^{\ddagger}=16.5 \mathrm{kcal} / \mathrm{mol}\right)$ is actually significant. Similar differences in calculated free energies of activation between members of the series $\left[(\mathrm{bda}) \mathrm{Ru}^{\mathrm{V}}(4-\mathrm{X}-\mathrm{py})_{2}(\mathrm{O})\right]^{+}(\mathrm{X}$ $=\mathrm{H}, \mathrm{Cl}, \mathrm{Br}, \mathrm{I})$ and $\left[(\mathrm{bda}) \mathrm{Ru}^{\mathrm{V}}(6-\mathrm{X} \text {-isq })_{2}(\mathrm{O})\right]^{+}(\mathrm{X}=\mathrm{H}, \mathrm{F}, \mathrm{Cl}, \mathrm{Br}, \mathrm{OMe})$ result in differences of an order of magnitude or more for the experimentally determined O-O coupling rate constants. ${ }^{46}$ Once again, if the bimolecular mechanism was operational for $\left[(b p c) R u^{\mathrm{V}}(\mathrm{L})_{2}(\mathrm{O})\right]$, we should expect to see evidence for it at much higher concentrations than for the corresponding $\left[(\text { bda }) \mathrm{Ru}^{\mathrm{V}}(\mathrm{L})_{2}(\mathrm{O})\right]^{+}$catalysts.

The single-site mechanism is expected to be operational for all $\mathrm{pH} \geq 1$ because the APT step is only accelerated in the presence of additional base, while the I2M step should not be $\mathrm{pH}$ dependent. However, the rate-determining step may change with increasing $\mathrm{pH}$ as the PCET oxidations become faster and the non-proton-coupled steps remain unaffected. 
(a)

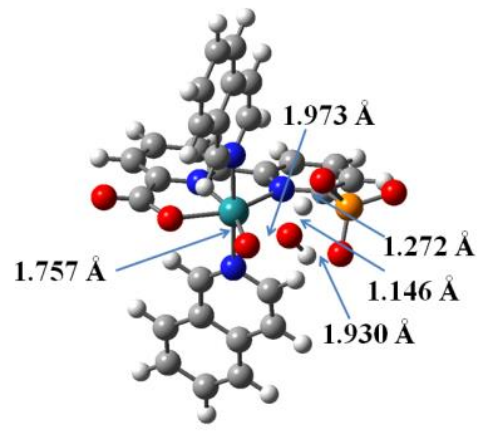

(b)

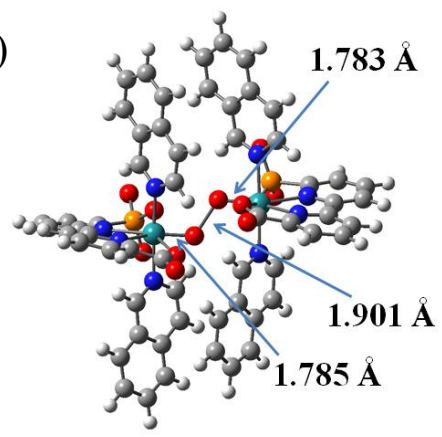

Figure 5. Transition state structures for $\mathrm{O}-\mathrm{O}$ bond formation for $\left[(\mathrm{bpc}) \mathrm{Ru}^{\mathrm{V}}(\mathrm{isq})_{2}(\mathrm{O})\right]$ via (a) single-site intramolecular atom-proton transfer ( $i$-APT) and (b) bimolecular oxo-oxo coupling (I2M).

Table 2. Transition state energies $\left(\Delta \mathrm{G}^{\ddagger}\right.$ in $\left.\mathrm{kcal} / \mathrm{mol}\right)$ for the single-site atom-proton transfer (APT) and bimolecular oxo-oxo coupling (I2M) steps of the $\mathrm{bpa}^{4-}, \mathrm{bpc}^{3-}$, and $\mathrm{bda}^{2-}$ catalysts.

\begin{tabular}{lll} 
Catalyst & APT & I2M \\
\hline$\left[(\mathrm{bpa}) \mathrm{Ru} \mathrm{V}^{\mathrm{V}}(\mathrm{py})_{2}(\mathrm{O})\right]^{-}$ & 10.2 & 31.9 \\
{$\left[(\mathrm{bpc}) \mathrm{Ru} \mathrm{V}^{\mathrm{V}}(\mathrm{py})_{2}(\mathrm{O})\right]$} & 11.7 & 21.0 \\
{$\left[(\mathrm{bpc}) \mathrm{Ru} \mathrm{V}^{\mathrm{V}}(\mathrm{isq})_{2}(\mathrm{O})\right]$} & 9.1 & 16.5 \\
$\left.\left[(\mathrm{bda}) \mathrm{Ru} \mathrm{V}^{\mathrm{isq}}\right)_{2}(\mathrm{O})\right]^{+}$ & 29.8 & 13.2
\end{tabular}

A hydrogen bonding interaction between the protonated phosphonate of the intermediate hydroperoxide, $\left[\left(\kappa^{3}-\mathrm{bpHc}\right) \mathrm{Ru}^{\mathrm{III}}(\mathrm{py})_{2}(\mathrm{OOH})\right]$, results in a $\mathrm{p} K_{\mathrm{a}}$ much higher than the preceding $\left[(\mathrm{bpHc}) \mathrm{Ru}^{\mathrm{III}}(\mathrm{py})_{2}\right]^{+}$intermediate $(3.73$ vs 1.03$)$. Thus, this is the most stable species under catalytic conditions. From this point, additional oxidation steps are required for the reaction to progress toward $\mathrm{O}_{2}$ release.

$\mathrm{O}_{2}$ evolution. Additional oxidation and proton loss steps are required until oxygen release becomes favorable. These steps are not expected to be rate-limiting because the calculated 
potentials required are all lower than those to reach $\mathrm{Ru}^{\mathrm{V}}=\mathrm{O}$. The calculated potential for oneelectron oxidation of six-coordinate $\left[\left(\kappa^{3}-\mathrm{bpHc}\right) \mathrm{Ru}^{\mathrm{III}}(\mathrm{py})_{2}(\mathrm{OOH})\right]$ to seven-coordinate $\left[(\mathrm{bpHc}) \mathrm{Ru}^{\mathrm{IV}}(\mathrm{py})_{2}(\mathrm{OOH})\right]^{+}$is $1.20 \mathrm{~V}$, below the preceding $\mathrm{Ru}^{\mathrm{IV} / I I I}$ and $\mathrm{Ru}^{\mathrm{V} / \mathrm{IV}}$ oxidative activation potentials. $\left[(\mathrm{bpHc}) \mathrm{Ru}^{\mathrm{IV}}(\mathrm{py})_{2}(\mathrm{OOH})\right]^{+}$has a calculated $\mathrm{p} K_{\mathrm{a}}$ of -0.68 for the phosphonic acid. Consequently, oxidation of $\left[\left(\kappa^{3}-b p H c\right) R u^{\text {III }}(p y)_{2}(\mathrm{OOH})\right]$ is most likely a PCET process, forming $\left[(\mathrm{bpc}) \mathrm{Ru}^{\mathrm{IV}}(\mathrm{py})_{2}(\mathrm{OOH})\right], \quad$ and $\quad$ the calculated $\quad\left[(\mathrm{bpHc}) \mathrm{Ru}^{\mathrm{IV}}(\mathrm{py})_{2}(\mathrm{OOH})\right]^{+} /\left[\left(\kappa^{3}-\right.\right.$ bpHc) $\left.\mathrm{Ru}^{\mathrm{III}}(\mathrm{py})_{2}(\mathrm{OOH})\right]$ potential of $1.20 \mathrm{~V}$ is an upper limit. In addition, the resulting triplet ${ }^{3}\left[(\mathrm{bpc}) \mathrm{Ru}^{\mathrm{IV}}(\mathrm{py})_{2}(\mathrm{OO})\right]^{-}$is more stable than the singlet ${ }^{1}\left[(\mathrm{bpc}) \mathrm{Ru}^{\mathrm{IV}}(\mathrm{py})_{2}(\mathrm{OO})\right]^{-}$by $6.6 \mathrm{kcal} / \mathrm{mol}$.

Oxygen evolution from ${ }^{3}\left[(\mathrm{bpc}) \mathrm{Ru}^{\mathrm{IV}}(\mathrm{py})_{2}(\mathrm{OO})\right]^{-}$to generate ${ }^{3} \mathrm{O}_{2}$ and ${ }^{1}\left[(\mathrm{bpc}) \mathrm{Ru}^{\mathrm{II}}(\mathrm{py})_{2}\right]^{-}$is a spin-allowed and energetically favorable process with $\Delta \mathrm{G}=-20.1 \mathrm{kcal} / \mathrm{mol}$, but it is kinetically inhibited at low $\mathrm{pH}$ where $\left[(\mathrm{bpc}) \mathrm{Ru}^{\mathrm{IV}}(\mathrm{py})_{2}(\mathrm{OOH})\right]$, which has a $\mathrm{p} K_{\mathrm{a}}$ of 3.24 , is the dominant species. Yet this is not an impediment because only $1.06 \mathrm{~V}$ is required for the $i$-PCET oxidation of ${ }^{3}\left[(\mathrm{bpc}) \mathrm{Ru}^{\mathrm{IV}}(\mathrm{py})_{2}(\mathrm{OOH})\right]$ to ${ }^{4}\left[(\mathrm{bpHc}) \mathrm{Ru}^{\mathrm{V}}(\mathrm{py})_{2}(\mathrm{OO})\right]^{+}$(step H). The calculated $\mathrm{p} K_{\mathrm{a}}$ for the latter is -0.82 and proton transfer to the bulk yields ${ }^{4}\left[(\mathrm{bpc}) \mathrm{Ru}^{\mathrm{V}}(\mathrm{py})_{2}(\mathrm{OO})\right]$ (step I).

Oxygen release (step J) is facile and spontaneous from both the doublet and quartet spin states of $\left[(\mathrm{bpc}) \mathrm{Ru}^{\mathrm{V}}(\mathrm{py})_{2}(\mathrm{OO})\right]$. Attempts to optimize ${ }^{2}\left[(\mathrm{bpc}) \mathrm{Ru}^{\mathrm{V}}(\mathrm{py})_{2}(\mathrm{OO})\right]$ led to spontaneous ${ }^{3} \mathrm{O}_{2}$ release and regeneration of ${ }^{2}\left[(\mathrm{bpc}) \mathrm{Ru}^{\mathrm{III}}(\mathrm{py})_{2}\right]$ and ${ }^{3} \mathrm{O}_{2}$ release from ${ }^{4}\left[(\mathrm{bpc}) \mathrm{Ru}^{\mathrm{V}}(\mathrm{py})_{2}(\mathrm{OO})\right]$ is very favorable with $\Delta \mathrm{G}=-34.6 \mathrm{kcal} / \mathrm{mol}$. The resulting ${ }^{2}\left[(\mathrm{bpc}) \mathrm{Ru}^{\mathrm{III}}(\mathrm{py})_{2}\right]$ re-enters the catalytic cycle.

The kinetic data discussed above suggest that the RDS is one of the oxidation steps. Based on the potentials, the $\mathrm{Ru}^{\mathrm{V}}=\mathrm{O} / \mathrm{Ru}^{\mathrm{IV}}=\mathrm{O}$ oxidation should be the most difficult, but ruthenium(IV/III) oxidations are known to be particularly slow. ${ }^{62}$ 


\section{Conclusion}

Single-site water oxidation catalysts featuring the new hybrid bpy-phosphonate-carboxylate ligand $\left(\mathrm{bpc}^{3-}\right)$ improve upon bpy-bisphosphonate $\left(\mathrm{bpa}^{4-}\right)$ catalysts with $200 \mathrm{mV}$ lower overpotential (330 mV at $\mathrm{pH} 1)$ and 50x faster catalysis. Turnover frequencies up to $107 \mathrm{~s}^{-1}$ were reached with $\left[(\mathrm{bpHc}) \mathrm{Ru}(\mathrm{isq})_{2}\right]$ and cerium(IV), which is fast for a single-site catalyst.

One argument against a WNA mechanism in the OEC is the low TOFs of single-site catalysts compared with those where $\mathrm{O}-\mathrm{O}$ bond formation takes place via radical coupling. Our studies show that properly designed single-site catalysts can reach TOFs rivaling those of the OEC on a per-site basis. Though turnover numbers for our new catalysts were limited to $\sim 70$ with cerium(IV) due to a competing inhibitory pathway, turnover numbers up to 1600 were reached with cobalt(III) as the oxidant. When properly designed, one site is still enough in water oxidation catalysis. Based on the high TOFs and TONs, this class of single-site catalysts represents a promising alternative to bimolecular catalysts, which tend to struggle when confined on semiconductor surfaces. Surface studies with these catalysts are ongoing.

\section{Experimental Section}

Synthetic Methods and Materials. The complexes described below are mildly air-sensitive. Reactions were carried out under argon using standard Schlenk techniques at ambient temperature $\left(21-24^{\circ} \mathrm{C}\right)$, unless otherwise noted. Workup and purification was performed in air. A vacuum desiccator was used for long term storage. Samples for analysis were prepared in air and used immediately. Paramagnetic oxidized impurities can be reduced by the addition of a small amount of ascorbic acid, which was necessary in some cases to obtain sharp NMR signals. High-purity water was obtained by passing house-distilled water through a Millipore Milli-Q UV-A system. 
Physical Methods. Nuclear magnetic resonance (NMR) spectra were recorded on a Bruker Avance III 400 spectrometer. ${ }^{1} \mathrm{H}$ NMR spectra were referenced to TMS using the residual protio impurities of the solvent. ${ }^{13} \mathrm{C}$ NMR spectra were referenced to TMS using the natural abundance ${ }^{13} \mathrm{C}$ of the solvent. ${ }^{19} \mathrm{~F}$ and ${ }^{31} \mathrm{P}$ NMR spectra, and ${ }^{13} \mathrm{C}$ NMR spectra in $\mathrm{D}_{2} \mathrm{O}$, were referenced to $\mathrm{CFCl}_{3}, \mathrm{H}_{3} \mathrm{PO}_{4}$, and TMS, respectively, using the $\Xi$ scale with the corresponding ${ }^{1} \mathrm{H}$ spectra. ${ }^{63}$ All chemical shifts are reported in the standard $\delta$ notation in parts per million; positive chemical shifts are a higher frequency than the reference. Electronic absorption spectra were recorded using an Agilent 8454 UV-vis spectrophotometer. Electrospray ionization mass spectrometry (ESI-MS) was performed with a Thermo Finnigan LCQ Advantage LC/MS/MS using methanol as the eluent, or at the Institute of Chemical Biology and Drug Discovery Analytical Instrumentation Laboratory in the Chemistry department at SUNY-Stony Brook on an Agilent LC-MSD using a methanol/aqueous eluent. Elemental analyses (EA) were performed by Robertson Microlit Laboratories (Ledgewood, NY, USA). Crystal structure data files have been deposited at the Cambridge Crystallographic Data Centre as CCDC 1541006 and CCDC 1541007 and can be obtained via www.ccdc.cam.ac.uk/structures/.

Electrochemical measurements were performed with a $\mathrm{CH}$ Instruments $\mathrm{CH}-760 \mathrm{E}$ bipotentiostat at ambient temperature $\left(21-24{ }^{\circ} \mathrm{C}\right)$ in a single compartment cell with a $3.0 \mathrm{~mm}$ glassy carbon disc working electrode, platinum wire counter electrode, and $\mathrm{Ag} / \mathrm{AgCl}(3 \mathrm{M} \mathrm{NaCl})$ reference electrode. The reference electrode was calibrated to the ruthenium(III/II) couple of an internal $\left[\mathrm{Ru}(\mathrm{bpy})_{3}\right]\left[\mathrm{PF}_{6}\right]_{2}$ standard at $1.26 \mathrm{~V}$ vs NHE. ${ }^{64}$ Unless otherwise noted, solutions contained $1.0 \mathrm{mM}$ analyte in aqueous solution containing nitric acid, phosphate buffer, or acetate buffer solutions. 
Stopped-flow kinetic measurements were performed at $25 \pm 0.1{ }^{\circ} \mathrm{C}$ with an Olis rapid scanning monochromator (Olis RSM-1000) equipped with an Olis USA stopped-flow. Pressure measurements were obtained with a Honeywell SDX30G2-A or SDX05G2-A pressure sensor connected via an instruNet i555 data acquisition system. Turnover frequencies (TOFs) were calculated from the observed rate constants $\left(k_{\text {obs }}\right)$ extracted from the data fitted with SPECFIT/32. Rate laws and overall rate constants $\left(k_{1,1}\right)$ were determined from plots of $\log [$ initial rate] vs $\log$ [catalyst] and $k_{\text {obs }}$ vs [Ru], respectively. Gaseous products were analyzed by gas chromatography (GC) on an Agilent 6890N network GC system.

Synthesis of (bpHc) $\mathbf{R u}(\mathbf{i s q})_{2} \cdot\left[\mathrm{RuCl}_{2}\left(\mathrm{C}_{6} \mathrm{H}_{6}\right)\right]_{2}(154.7 \mathrm{mg}, 309.3 \mu \mathrm{mol}, 0.56$ equiv) and $\mathrm{bpH}_{2} \mathrm{cH} \cdot \mathrm{HCl}(173.4 \mathrm{mg}, 547.6 \mu \mathrm{mol}, 1$ equiv) were suspended in $16 \mathrm{~mL}$ anhydrous methanol. The mixture was degassed by bubbling with argon for $10 \mathrm{~min}$, then heated to reflux for $3 \mathrm{~h}$. The dark purple reaction mixture was removed from heat and treated with triethylamine $(518 \mu \mathrm{L}$, $3.72 \mathrm{mmol}, 6.8$ equiv) and isoquinoline (149 $\mu \mathrm{L}, 1.27 \mathrm{mmol}, 2.32$ equiv). After an additional $11.5 \mathrm{~h}$ reflux, the dark orange reaction mixture was cooled to room temperature and filtered. The filtrate was evaporated to dryness. The resulting residue was redissolved in $3 \mathrm{~mL} 0.05 \mathrm{M}$ $\mathrm{NaOH}_{(\mathrm{aq})}$ and filtered with a syringe filter. An additional $2 \times 1 \mathrm{~mL} 0.05 \mathrm{M} \mathrm{NaOH}_{(\mathrm{aq})}$ was used to rinse the remaining residue from the flask and filter. To the resulting solution was added $1.5 \mathrm{~mL}$ $0.5 \mathrm{M} \mathrm{HClO}_{4}$, which effected precipitation of the product. After filtration, the brown solid was washed with $3 \times 2 \mathrm{~mL} 0.1 \mathrm{M} \mathrm{HClO}_{4}, 2 \times 2 \mathrm{~mL} \mathrm{H}_{2} \mathrm{O}$, and $2 \times 5 \mathrm{~mL} \mathrm{Et}_{2} \mathrm{O}$, then dried in vacuo. Elemental analysis showed that the solid retained approximately 1.5 equiv $\mathrm{H}_{2} \mathrm{O}(339.1 \mathrm{mg}$, $93 \%)$.

${ }^{1} \mathrm{H}$ NMR $(0.10 \mathrm{M} \mathrm{NaOD}) \delta(\mathrm{ppm}): 8.33\left(d,{ }^{3} J_{\mathrm{HH}}=8.0 \mathrm{~Hz}, 1 \mathrm{H}, \operatorname{aryl}-\mathrm{H}\right), 8.24\left(d,{ }^{3} J_{\mathrm{HH}}=7.8 \mathrm{~Hz}\right.$, $1 \mathrm{H}$, aryl-H), $8.01\left(s, 2 \mathrm{H}\right.$, isq aryl-H), $7.81\left(t d,{ }^{3} J_{\mathrm{HH}}=7.9 \mathrm{~Hz},{ }^{3} J_{\mathrm{HP}}=3.1 \mathrm{~Hz}, 1 \mathrm{H}\right.$, aryl-H), 7.66- 
$7.59(m, 2 \mathrm{H}, \operatorname{aryl}-\mathrm{H}), 7.55\left(d,{ }^{3} J_{\mathrm{HH}}=6.5 \mathrm{~Hz}, 2 \mathrm{H}\right.$, isq aryl-H), $7.44\left(t,{ }^{3} J_{\mathrm{HH}}=7.9 \mathrm{~Hz}, 1 \mathrm{H}\right.$, aryl-

$\mathrm{H}), 7.22-7.04\left(m, 8 \mathrm{H}\right.$, isq aryl-H), $7.01\left(t,{ }^{3} J_{\mathrm{HH}}=7.4 \mathrm{~Hz}, 2 \mathrm{H}\right.$, isq aryl-H). ${ }^{13} \mathrm{C}\left\{{ }^{1} \mathrm{H}\right\}$ NMR $(0.10$ $\mathrm{M} \mathrm{NaOD}+$ ascorbic acid) $\delta(\mathrm{ppm}): 174.9\left(-\mathrm{CO}_{2}\right), 164.3\left(d,{ }^{1} J_{\mathrm{CP}}=217 \mathrm{~Hz}\right.$, aryl-C), 161.0 (arylC), $158.9\left(d,{ }^{3} J_{\mathrm{CP}}=9 \mathrm{~Hz}\right.$, aryl-C), 155.3 (aryl-C), 155.1 (aryl-C), 143.0 (aryl-C), 134.0 (arylC), $132.9\left(d,{ }^{2} J_{\mathrm{CP}}=8 \mathrm{~Hz}\right.$, aryl-C), 131.5 (aryl-C), 130.4 (aryl-C), 127.9 (aryl-C), 127.8 (arylC), $127.3\left(d,{ }^{3} J_{\mathrm{CP}}=17 \mathrm{~Hz}\right.$, aryl-C), 126.6 (aryl-C), 125.8 (aryl-C), 125.8 (aryl-C), 124.8 (arylC), 124.1 (aryl-C), 121.3 (aryl-C). ${ }^{31} \mathrm{P}\left\{{ }^{1} \mathrm{H}\right\}$ NMR (0.10 M NaOD) $\delta$ (ppm): 25.4. UV-vis (0.1 M $\left.\mathrm{HNO}_{3}\right) \lambda_{\max } / \mathrm{nm}\left(\epsilon / \mathrm{M}^{-1} \mathrm{~cm}^{-1}\right): 298$ (35 900), 406 (14 500), 331 (7 560). ESI-MS $\left(\mathrm{H}_{2} \mathrm{O}\right) \mathrm{m} / \mathrm{z}$ (calcd., found): $\left[(\mathrm{bpHc}) \mathrm{Ru}(\mathrm{isq})_{2}+\mathrm{H}\right]^{+}(639.0,638.9),\left[(\mathrm{bpHc}) \mathrm{Ru}(\mathrm{isq})_{2}+\mathrm{Na}\right]^{+}(661.0,660.9)$. Analysis (calcd., found for $\left.\mathrm{C}_{29} \mathrm{H}_{21} \mathrm{~N}_{4} \mathrm{O}_{5} \mathrm{PRu} \cdot 1.5 \mathrm{H}_{2} \mathrm{O}\right)$ : $\mathrm{C}(52.41,52.53), \mathrm{H}(3.64,3.52), \mathrm{N}(8.43$, 8.40).

Supporting Information. Additional methods, including syntheses, characterization, electrochemical data, kinetic data, crystallographic details, and computational details and structures. This material is available free of charge via the Internet at http://pubs.acs.org.

\section{Corresponding Author.}

*jconcepc@bnl.gov

Acknowledgement. This work was carried out at Brookhaven National Laboratory and it was supported by the U.S. Department of Energy, Office of Science, Division of Chemical Sciences, Geosciences, \& Biosciences, Office of Basic Energy Sciences under contract DE-SC00112704.

\section{References}

(1) McKone, J. R.; Lewis, N. S.; Gray, H. B. Chem. Mater. 2014, 26, 407.

(2) McCrory, C. C. L.; Jung, S.; Ferrer, I. M.; Chatman, S. M.; Peters, J. C.; Jaramillo, T. F. J. Am. Chem. Soc. 2015, 137, 4347. 
(3) Kärkäs, M. D.; Verho, O.; Johnston, E. V.; Åkermark, B. Chem. Rev. 2014, 114,

(4) Shaner, M. R.; Atwater, H. A.; Lewis, N. S.; McFarland, E. W. Energy Environ. Sci. 2016, 9, 2354.

(5) Chen, Y.; Hu, S.; Xiang, C.; Lewis, N. S. Energy Environ. Sci. 2015, 8, 876.

(6) Dau, H.; Limberg, C.; Reier, T.; Risch, M.; Roggan, S.; Strasser, P. ChemCatChem 2010, 2, 724.

(7) Sproviero, E. M.; Gascón, J. A.; McEvoy, J. P.; Brudvig, G. W.; Batista, V. S. J. Am. Chem. Soc. 2008, 130, 3428.

(8) McEvoy, J. P.; Brudvig, G. W. Chem. Rev. 2006, 106, 4455.

(9) Taguchi, T.; Gupta, R.; Lassalle-Kaiser, B.; Boyce, D. W.; Yachandra, V. K.; Tolman, W. B.; Yano, J.; Hendrich, M. P.; Borovik, A. S. J. Am. Chem. Soc. 2012, 134, 1996.

(10) Pecoraro, V. L.; Baldwin, M. J.; Caudle, M. T.; Hsieh, W. Y.; Law, N. A. In Pure Appl. Chem. 1998; Vol. 70, p 925.

(11) Isobe, H.; Shoji, M.; Yamanaka, S.; Umena, Y.; Kawakami, K.; Kamiya, N.; Shen, J. R.; Yamaguchi, K. Dalton Trans. 2012, 41, 13727.

(12) Siegbahn, P. E. M. Biochimica et Biophysica Acta (BBA) - Bioenergetics 2013, $1827,1003$.

(13) Messinger, J. Phys. Chem. Chem. Phys. 2004, 6, 4764.

(14) Vinyard, D. J.; Ananyev, G. M.; Dismukes, G. C. Annu. Rev. Biochem. 2013, 82, 577.

(15) Siegbahn, P. E. M. Chem.--Eur. J. 2006, 12, 9217.

(16) Sala, X.; Maji, S.; Bofill, R.; García-Antón, J.; Escriche, L.; Llobet, A. Acc. Chem. Res. 2014, 47, 504.

(17) Clark, A. E.; Hurst, J. K. In Prog. Inorg. Chem.; Karlin, K. D., Ed.; John Wiley \& Sons, Inc.: Hoboken, NJ, USA, 2011; Vol. 57, p 1.

(18) Bozoglian, F.; Romain, S.; Ertem, M. Z.; Todorova, T. K.; Sens, C.; Mola, J.; Rodríguez, M.; Romero, I.; Benet-Buchholz, J.; Fontrodona, X.; Cramer, C. J.; Gagliardi, L.; Llobet, A. J. Am. Chem. Soc. 2009, 131, 15176.

(19) Romain, S.; Bozoglian, F.; Sala, X.; Llobet, A. J. Am. Chem. Soc. 2009, 131, 2768.

(20) Duan, L.; Fischer, A.; Xu, Y.; Sun, L. J. Am. Chem. Soc. 2009, 131, 10397.

(21) Duan, L.; Bozoglian, F.; Mandal, S.; Stewart, B.; Privalov, T.; Llobet, A.; Sun, L. Nature Chem. 2012, 4, 418.

(22) Wang, L.; Duan, L.; Stewart, B.; Pu, M.; Liu, J.; Privalov, T.; Sun, L. J. Am. Chem. Soc. 2012, 134, 18868.

(23) Concepcion, J. J.; Zhong, D. K.; Szalda, D. J.; Muckerman, J. T.; Fujita, E. Chem. Commun. 2015, 51, 4105.

(24) Concepcion, J. J.; Jurss, J. W.; Templeton, J. L.; Meyer, T. J. J. Am. Chem. Soc. 2008, 130, 16462.

(25) Chen, Z.; Concepcion, J. J.; Jurss, J. W.; Meyer, T. J. J. Am. Chem. Soc. 2009, 131,15580 .

(26) Concepcion, J. J.; Jurss, J. W.; Brennaman, M. K.; Hoertz, P. G.; Patrocinio, A. O. T.; Murakami Iha, N. Y.; Templeton, J. L.; Meyer, T. J. Acc. Chem. Res. 2009, 42, 1954.

(27) Concepcion, J. J.; Tsai, M.-K.; Muckerman, J. T.; Meyer, T. J. J. Am. Chem. Soc. 2010, 132, 1545. 
(28) Lin, X.; Hu, X.; Concepcion, J. J.; Chen, Z.; Liu, S.; Meyer, T. J.; Yang, W. Proc. Natl. Acad. Sci. U.S.A. 2012, 109, 15669.

(29) Zhang, G.; Zong, R.; Tseng, H.-W.; Thummel, R. P. Inorg. Chem. 2008, 47, 990.

(30) Tseng, H.-W.; Zong, R.; Muckerman, J. T.; Thummel, R. Inorg. Chem. 2008, 47, 11763.

(31) Masaoka, S.; Sakai, K. Chem. Lett. 2009, 38, 182.

(32) Yoshida, M.; Masaoka, S.; Sakai, K. Chem. Lett. 2009, 38, 702.

(33) Chen, Z.; Concepcion, J. J.; Hu, X.; Yang, W.; Hoertz, P. G.; Meyer, T. J. Proc. Natl. Acad. Sci. U.S.A. 2010, 107, 7225.

(34) Concepcion, J. J.; Jurss, J. W.; Norris, M. R.; Chen, Z.; Templeton, J. L.; Meyer, T. J. Inorg. Chem. 2010, 49, 1277.

(35) Gagliardi, C. J.; Vannucci, A. K.; Concepcion, J. J.; Chen, Z.; Meyer, T. J. Energy Environ. Sci. 2012, 5, 7704.

(36) Meyer, T. J. J. Electrochem. Soc. 1984, 131, 221C.

(37) Dovletoglou, A.; Adeyemi, S. A.; Lynn, M. H.; Hodgson, D. J.; Meyer, T. J. J. Am. Chem. Soc. 1990, 112, 8989.

(38) Dovletoglou, A.; Meyer, T. J. J. Am. Chem. Soc. 1994, 116, 215.

(39) Meyer, T. J.; Huynh, M. H. V. Inorg. Chem. 2003, 42, 8140.

(40) Roecker, L.; Dobson, J. C.; Vining, W. J.; Meyer, T. J. Inorg. Chem. 1987, 26, 779.

(41) Xie, Y.; Shaffer, D. W.; Lewandowska-Andralojc, A.; Szalda, D. J.; Concepcion, J. J. Angew. Chem., Int. Ed. 2016, 55, 8067.

(42) Walden, A. G.; Miller, A. J. M. Chem. Sci. 2015, 6, 2405.

(43) Matheu, R.; Ertem, M. Z.; Benet-Buchholz, J.; Coronado, E.; Batista, V. S.; Sala, X.; Llobet, A. J. Am. Chem. Soc. 2015, 137, 10786.

(44) López, I.; Ertem, M. Z.; Maji, S.; Benet-Buchholz, J.; Keidel, A.; Kuhlmann, U.; Hildebrandt, P.; Cramer, C. J.; Batista, V. S.; Llobet, A. Angew. Chem., Int. Ed. 2014, 53, 205.

(45) Tong, L.; Inge, A. K.; Duan, L.; Wang, L.; Zou, X.; Sun, L. Inorg. Chem. 2013, $52,2505$.

(46) Xie, Y.; Shaffer, D. W.; Concepcion, J. J. submitted 2017.

(47) Wang, L.; Duan, L.; Wang, Y.; Ahlquist, M. S. G.; Sun, L. Chem. Commun. 2014, $50,12947$.

(48) Due to the poor solubility of the isoquinoline complex, potentials were measured in $0.1 \mathrm{M}$ nitric acid, see Figure S8 and Figure S9.

$260,21$.

(49) Piro, N. A.; Robinson, J. R.; Walsh, P. J.; Schelter, E. J. Coord. Chem. Rev. 2014,

(50) Shaffer, D. W.; Xie, Y.; Szalda, D. J.; Concepcion, J. J. Inorg. Chem. 2016, 55, 12024.

(51) Wang, R. C.; Zhang, Y.; Hu, H.; Frausto, R. R.; Clearfield, A. Chem. Mater. 1992, 4, 864 .

(52) Kovacs, M. S.; Monga, V.; Patrick, B. O.; Orvig, C. Dalton Trans. 2006, 31.

(53) Chandrasekhar, V.; Sasikumar, P. Dalton Trans. 2008, 6475.

(54) Campello, M. P. C.; Lacerda, S.; Santos, I. C.; Pereira, G. A.; Geraldes, C. F. G. C.; Kotek, J.; Hermann, P.; Vaněk, J.; Lubal, P.; Kubíček, V.; Tóth, É.; Santos, I. Chem.--Eur. J. 2010, 16, 8446.

(55) Johnson, D. A.; Nelson, P. G. J. Chem. Soc., Dalton Trans. 1990, 1. 
(56) Macartney, D. H.; Sutin, N. Inorg. Chem. 1985, 24, 3403.

(57) Young, R. C.; Keene, F. R.; Meyer, T. J. J. Am. Chem. Soc. 1977, 99, 2468.

(58) Pyridine is used in place of picoline due to the facile rotation of the methyl group. Results are generally in agreement with experiment where available.

(59) Duan, L.; Araujo, C. M.; Ahlquist, M. S. G.; Sun, L. Proc. Natl. Acad. Sci. U.S.A. 2012, 109, 15584.

(60) Duan, L.; Wang, L.; Li, F.; Li, F.; Sun, L. Acc. Chem. Res. 2015, 48, 2084.

(61) Tong, L.; Duan, L.; Xu, Y.; Privalov, T.; Sun, L. Angew. Chem., Int. Ed. 2011, 50,445 .

(62) Chen, Z.; Vannucci, A. K.; Concepcion, J. J.; Jurss, J. W.; Meyer, T. J. Proc. Natl. Acad. Sci. U.S.A. 2011, 108, E1461.

(63) Harris, R. K.; Becker, E. D.; Cabral de Menezes, S. M.; Goodfellow, R.; Granger, P. Pure Appl. Chem. 2001, 73, 1795.

(64) Juris, A.; Balzani, V.; Barigelletti, F.; Campagna, S.; Belser, P.; von Zelewsky, A. Coord. Chem. Rev. 1988, 84, 85.

For Table of Contents Only

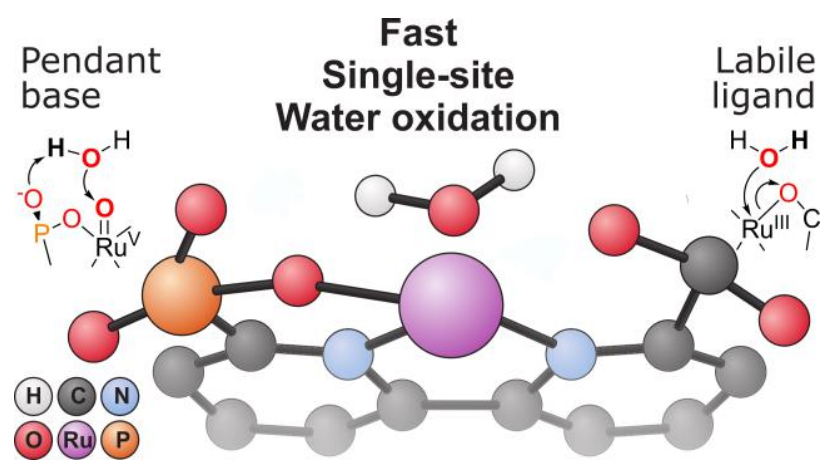

